\title{
Media Frame Building and Culture: Transgenic crops in two Brazilian Newspapers during the "Year of Controversy"
}

\author{
Dominique Brossard, Luisa Massarani, \\ Carla Almeida, Bruno Buys, Emily Acosta Lewis
}

\section{Abstract}

Brazil is the second world producer of transgenic crops. However, intense controversies were around their introduction in the country. This study analyzes media coverage of GM crops in two elite Brazilian newspapers, Folha de S. Paulo and $O$ Globo, in 2003, the "Year of Controversy", a period of intense political debate over the issue. Using issue attention cycle and media frame building as theoretical frameworks, we combine quantitative content analysis and in-depth individual interviews with journalists to identify the main influencers of media coverage. Our study revealed that the two newspapers covered the issue differently than in the United States. North American newspapers tended to emphasize dramatic elements when the GM issue was discussed in the political arena; in Brazil, technical elements were a major focus in the stories.

\section{Keywords}

Transgenic crops. Content analysis. Attention cycle. Media frame building. Newspapers.
Dominique Brossard I dbrossard@wisc.edu $\mathrm{PhD}$ in Communication at the Cornell University. Researcher at the Department of Life Sciences Communication, University of WisconsinMadison, USA.

Luisa Massarani | lumassa@fiocruz.br and luisa. massarani2@gmail.com

$\mathrm{PhD}$ in Education and Communication in Biosciences at the Federal University of Rio de Janeiro (UFRJ). Researcher and journalist at the Studies on Science Communication at Museu da Vida/Casa de Oswaldo Cruz/Fundação Oswaldo Cruz, Rio de Janeiro.

Carla Almeida | almeidacarla@gmail.com $\mathrm{PhD}$ in Education and Communication in Biosciences at the Federal University of Rio de Janeiro (UFRJ). Jornalist and Editor of Ciência Hoje On-line.

Bruno Buys | bruno@buys.net.br Diploma course in Science Journalism at the State University of Campinas (Unicamp). Works at the Ambiental do Instituto Brasileiro do Meio Ambiente e dos Recursos Naturais Renováveis (Ibama).

Emily Acosta Lewis I emily.acostalewis@wne.edu PhD in Communication at the University of Wisconsin-Madison, USA. Assistant professor in Communication at the Western New England University, USA.

\section{Introduction ${ }^{1}$}

For the last two decades, mass communication researchers have been interested in understanding the way mass media portrays important issues, with "framing" being one of the concepts of choice for studying how journalistic messages convey meaning. Media frames represent the 
way in which a specific mediated message is packaged and presented (GAMSON; MODIGLIANI, 1989). In other words, frames refer to the modes of presentation journalists use to make complex issues accessible to readers (GANS, 1979). Numerous conceptualizations of frames (and framing) have been proposed and debated (SCHEUFELE, 1999; TEWKSBURY; SCHEUFELE, 2008), and it is not the goal of the present article to reopen or summarize the debate. We are here interested in discussing what leads specific frames to be predominant in a story, a selection process labeled as media frame building (SCHEUFELE, 1999).

Past research suggest that five main factors may affect how an issue is framed in a news story, including social norms and values, organizational pressures and constraints, interest group pressure, journalistic routines, journalist ideology/ politics, and audience values (SCHEUFELE, 1999; TUCHMAN, 1978). Journalists are considered to be "gatekeepers," who apply so-called "news values" to select the most important information for the public (SHOEMAKER; REESE, 1996). In order for events, story ideas, and issues to become news, they must go through a process of appraisal, with journalists resorting to certain criteria (or news values: timeliness, prominence, significance, proximity, conflict, and human interest) to reach a judgment (GANT; DIMMICK, 2000). These news values may indirectly affect the frames that are used in the story. At the same time, journalists may thrive for objectivity and balance by showing all sides of the debate without taking a position on the issue covered while being also subject to their own ideological biases. Organizational constraints linked to media structure will likely influence which stories are covered and why. Finally, external influences are likely to be important forces in shaping the media agenda, with interest and elite groups shaping attempting to influence media content through press releases and other concerted communication efforts (TEWKSBURY; SCHEUFELE, 2008).

The issue attention cycle was introduced by Downs (1972) as a connection between the press and policy aspects of an issue. Downs stated that the public does not maintain close attention to any one domestic issue over a long period of time even if the issue has important societal implications. Instead, public attention displays a systematic cyclical pattern, characterized first by increased interest, a plateau and decreasing interest. According to Downs, issues go through five stages of attention: a pre-problem stage, alarmed discovery following a specific event raising concern (or euphoric enthusiasm, realizing the cost or benefits of a specific situation), gradual decline of public interest, and the post-problem stage. The cycle is likely to repeat itself as the issue comes to the attention again through new events. 
North American media coverage of a large number of environmental issues has shown the cyclical frequency pattern Downs proposed. For instance, the quantitative ups and downs of American media attention to global climate change have been well documented (MAZUR; LEE, 1993; McCOMAS; SHANAHAN, 1999; TRUMBO, 1996; UNGAR, 1992). However, Downs' explanation for the attention cycle, which focused mainly on the nature of the issue at stake and objective facts related to that issue, has also been criticized, many contemporary scholars going beyond the hypothesis and attempting to propose other explanations for such a cyclical pattern - among others, see Hilgartner e Bosk (1988), McComas e Shanahan (1999), Trumbo (1996) e Ungar (1992). Many of these explanations object to the linear focus of Downs' hypothesis and prefer to emphasize the social construction of issue cycles.

Since frames are narrative devices used by journalists, Nisbet and Huge - along the lines of Shanahan e McComas (1999) asserted that frames' nature would vary as an issue develops and comes under public scrutiny (NISBET; HUGE, 2006). Using Downs' issue attention cycle as the backbone of a mediated issue development model and agricultural biotechnology as a case study, Nisbet and Huge argued that the policy venue in which a debate is taking place is a major determinant of the type of media frames used in the coverage of a politicized controversial issue (see Figure 1). Depending on the stage of issue development, dramatic or technical frames will be

Figure 1: Mediated Issue Development Model (reproduced with permission from Nisber \& Huge, 2006)

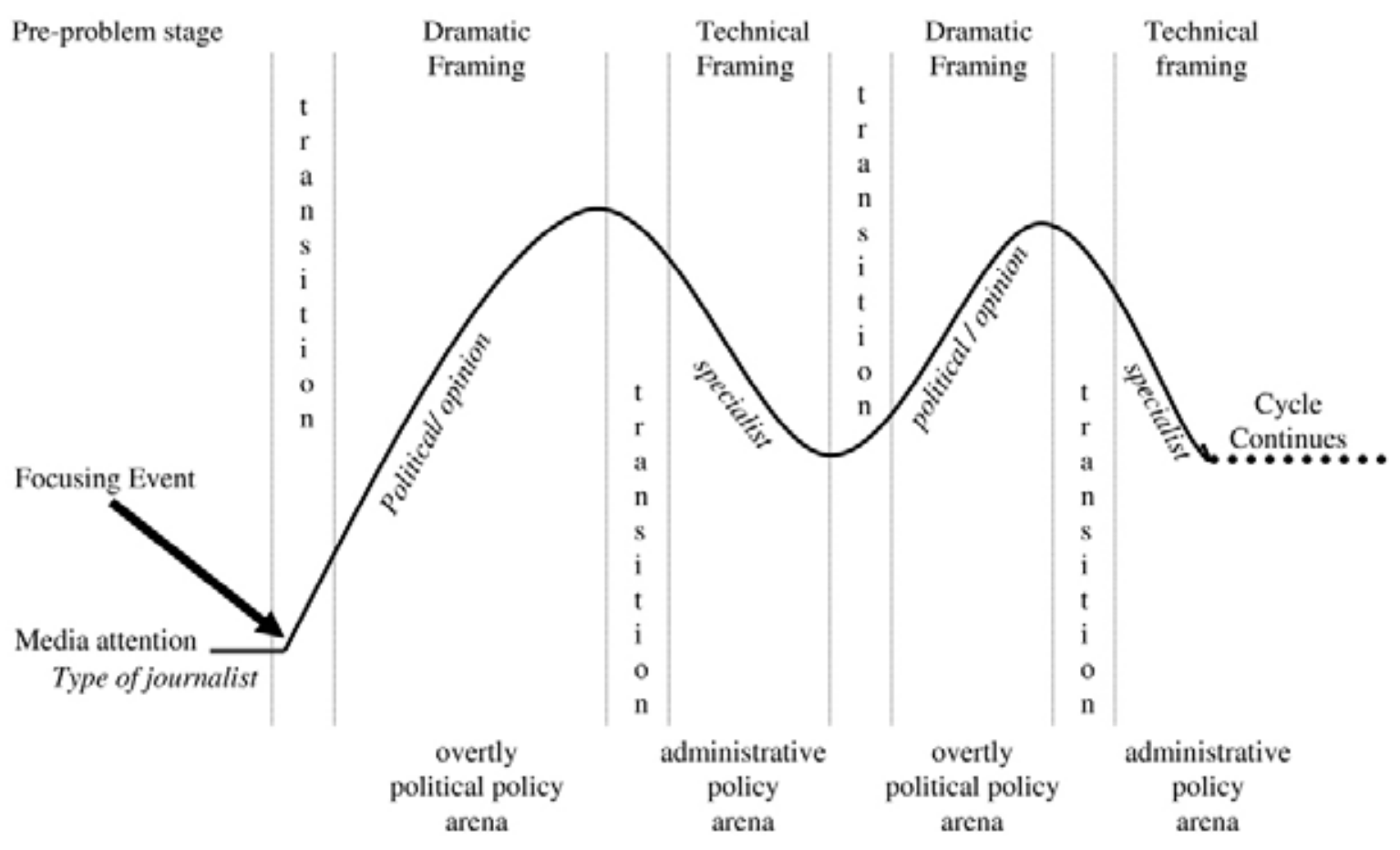


emphasized in media coverage, technical framing (i.e. scientific background or policy or regulatory background) tending to be used when the issue is in an administrative arena and media attention is decreasing (NISBET; HUGE, 2006); technical writers (such as science writers will often be the authors of the articles which tend to be located in the science sections. Dramatic framing (i.e focus on conflict, morality, of scientific uncertainty) tend to be predominant when the issue is in an overtly political arena and more voices are heard in the debate, all attempting to frame the issue in a way that will foster media attention. At this stage, the volume of media coverage tends to increase. In other words and according to this framework, media attention (and framing) are driven by the policy arena in which the issue is under discussion more than by the nature of the issue itself.

Other scholars have argued that culture plays an important role in explaining the cyclical attention media pays to environmental and scientific issues (BROSSARD; SHANAHAN; McCOMAS, 2004).

A comparison of French and North American Coverage of global climate change, for instance, showed that although the North American coverage tended to follow the cycle suggested by Downs, this was not the case for the French coverage, which seemed to be event (rather that cycle) driven (BROSSARD; SHANAHAN; MCCOMAS, 2004). One explanation put forward was that journalistic practices in the United States (such as balance and objectivity) were one of the major forces driving the media attention cycle; since these practices were different in France, the cycle did not have the same pattern.

The present study uses media coverage of transgenic crops - also called here in its broader concept as Genetically Modified (GM) crops - in Brazil to test Nisbet's mediated model of issue attention cycle in another political and social context. It examines how culture might impact media frame building, while taking into account the cycle of media attention, as well as journalistic practices and organizational routines. We will focus on the year of 2003, which we call the "Year of Controversy", due to the fact that it was a period of very intense political debate about GM crops in Brazil, the second world producer of GM crops.

\section{Case Study: Genetically Modified crops in Brazil}

Brazil is the second largest grower of Genetically Modified (GM) crops in the world, next to the US, according to the International Service for the Acquisition of Agri-biotech Applications (ISAAA). In 2011, Brazil grew 30.3 million hectares of GM crops, an increase of 4.9 million hectares (19\%) compared with 2010, largest increase in any country in the world. (ISAAA, 2012)

Brazil leading position in GM crop production was achieved despite an intense controversy in the country over GM technology that has been running for more than a decade. Since 1998, when attempts 
to produce GM crops on a commercial scale were made, the debate surrounding GM crops had involved different sectors of society, both in rural and urban areas. Growing and selling GM crops was prohibited until March 2005 (special permissions were provided as we will detail further below), when the "Biosafety Law" was approved, after 17 months of intense debate by the Brazilian parliamentarians (BRASIL, 2005). For further details on the legislative debate in the National Congress, see Dolabella, Araujo e Faria (2005).

The controversy around GM crops reached a peak in February 2003 when it was formally announced that a major proportion of Brazilian soybean crops were transgenic due to illegal planting, mainly in the Southern state of Rio Grande do Sul (almost 90 percent of the soybean crops in Rio Grande do Sul and about 8 percent of the Brazilian soybean harvest came from illegal planting). Rio Grande do Sul borders Argentina, where GM crops are widespread. Shortly after an announcement maintaining the ban on GM crops despite the situation, the government decided to allow the sale of GM soya for animal and human consumption, sparking protest within the government and from environmental groups (the decision was initially limited to the 2003 harvest, but this was expanded to other harvests later on). The government argued that this decision had been taken because of the important social and economic problems raised by the existing billions of tons of transgenic soybean. Also the large number of small farmers involved in the issue could not afford to have their crops destroyed.
The public was predominantly opposed to the governmental decision. According to a survey conducted in November and December of 2003 with a national sample of 16 years old and older, 73 percent of the population thought transgenic crops should be prohibited until all the important questions concerning the risks involved were adequately addressed (IBOPE, 2003).

\section{The Study}

The objective of the present study is to map out how two elite Brazilian newspapers covered the issue of transgenic crops in 2003, a period of intense political and public debate. Based on Nisbet's model of mediated issue development model, one would expect dramatic frames to be predominant during that year since the issue was predominantly in the political arena. However, one may wonder to what extent the specific socio-political context of Brazil, as well as the journalistic routines in that country, may have affected the coverage and more specifically the type of framing predominant in print news stories.

As case studies, we chose two major national newspapers in Brazil, Folha e $O$ Globo, due to their status in Brazil and their localization (they are published in the two most important (culturally and economically speaking) Brazilian cities, $O$ Globo in Rio de Janeiro and Folha in São Paulo. Readership for the newspapers is similar, with readers coming from the middle to upper class. Both are elite newspapers and are considered a 
reference source for policymakers. Folha average

daily circulation is 326.476 on Mondays to

Saturdays and 384.184 on Sundays. ${ }^{2}$ O Globo has a

daily circulation average of 269,053 on Mondays to

Saturdays and 375,188 on Sundays. ${ }^{3}$

In light of the previous discussions, we posit the

following research question:

Research Question 1: what is the nature of the coverage of a controversial scientific issue such as GM crop when it is discussed in the "political arena" in Brazil?

In other words, is the coverage of GM crops in Folha and $O$ Globo consistent with the mediated issue development cycle proposed by Nisbet e Huge (2006)?

RQ1a: are dramatic frames predominant in 2003 media coverage of GM crops in Folha and $O$ Globo coverage of the GM crop issue?

We also aim to identify, beyond considering the developmental stage of the GM issue in Brazil, what is the frame building process leading Brazilian journalists to focus on specific angles and content when reporting on the GM crop issue. We therefore posit the following research questions:
Research Question 2: how culturally bound is the media frame-building process? RQ2a: what are the news values Brazilian journalists rely on when constructing stories about GM crops?

Our study relied on a combination of quantitative and qualitative methods, by conducting a quantitative content analysis of newspapers' stories and in-depth interviews with the journalists who wrote the stories, as well as with the editors of the sections in which the stories were published.

All newspaper articles on transgenics published in 2003 by Folh $a$ and $O$ Globo were collected. The articles were identified by using the keywords "transgênico" and "transgênicos" ("transgenic" and "transgenics") in an electronic archive, yielding a total sample of $\mathrm{N}=330$ stories $(0$ Globo $=73 ;$ Folh $a=257)$. The newspaper article was the unit of analysis, and editorials were excluded from the sample. It should be noted that since all articles on transgenic crops were included (i.e we obtained a census population), we do not need to rely on statistical analysis to test the significance of the potential differences to be observed.

The quantitative content analysis was performed with the use of a coding sheet developed in the

Figures provided by the commercial section of Folha, on 19 January 2006.

Information provided by the Instituto Verificador de Circulação (IVC), organization which controls the number of issues per publication in Brazil, on 15 December 2011. 
context of a published study on GM crops and print media (NISBET et al, 2003). Ten percent of the articles were coded by a second coder, to assess intercoder reliability (average Scott's pi across variables $=0.80$ ).

We identified Technicalframes and Dramatic frames in the coverage. Technical frames included "new research," "scientific background," "policy and/or regulatory background," "market/ economic prospects," and "patenting or property rights." Dramatic frames included "ethics and morality," "conflict and strategy," "scientific uncertainty," and "public opinion" (see Appendix 1 for a description of the frames). Each frame was coded as 0 (not present), 1 (present) or 2 (prominent, in the headline of opening paragraph).

We also recorded the section in which the article appeared (national news; science; business/ economy, others), as well as the sources mentioned in the articles (academy, business, economists, experts, independent research, government, and environmental sources). Policy arenas mentioned in the articles were also recorded (Brazilian policy arenas, American policy arenas; other international policy arenas).

In-depth interviews were conducted with six journalists, as the following: two journalists who covered GM crops for Folha, one science editor of Folha, two journalists who covered GM crops for $O$ Globo, and one science editor of $O$ Globo. Both science editors had also been writing stories about
GM crops for several years previous to becoming editors. The interviews were semi-structured, the interviewer having a list of themes to be addressed and providing a framework for discussion. The goal was to not prime the journalists to answer in specific ways. Each interview lasted approximately one hour.

Two hundred fifty six pages (double spaced) of typed interview transcripts were text analyzed to identify which news values each journalist relied on when writing stories about GM crops. Consistent with past research, we categorized news values in terms of impact, timeliness, prominence, proximity, bizarreness, conflict, and currency. It was noted whether respondents used these as reasons to cover the issue of GM specifically, as opposed to a more general stand on news writing. We also recorded whether interviewees mentioned or discussed the ideas of balance and objectivity, which are two concepts often put forward as crucial writing objectives by American journalists. Finally, we noted the Potential influencers on coverage mentioned by the journalists (i.e. social norms/values, organizational pressure/constraints, interest group pressure, journalistic routines, journalist ideology and training, and audience values). Sources mentioned by the journalists were also recorded.

\section{Results and Discussion}

\section{Nature of the Coverage}

Folha and $O$ Globo published a large number of stories on the issue of GM crops in 2003. 


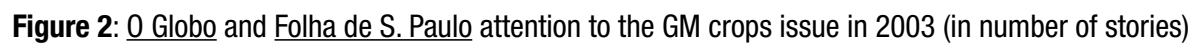

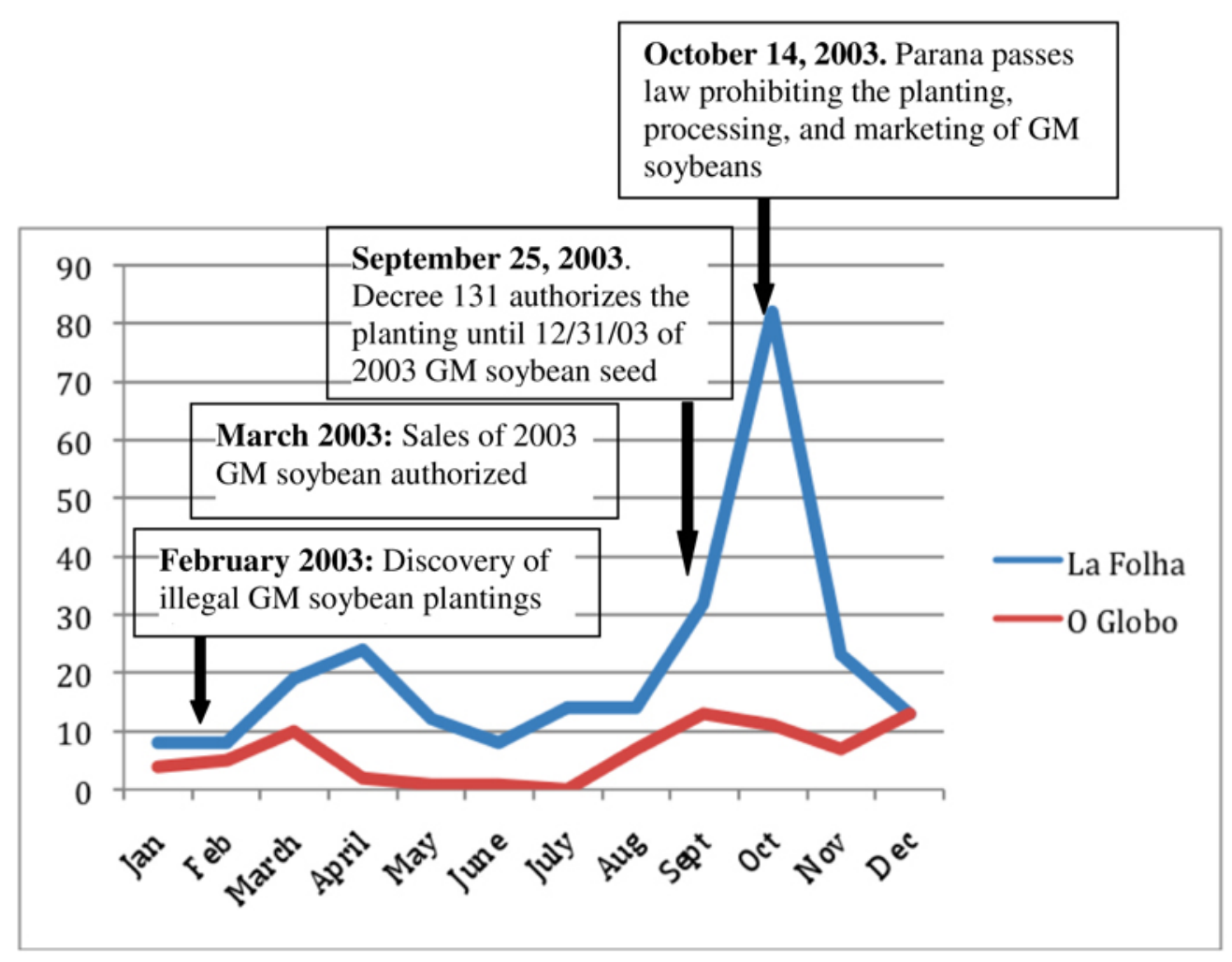

Folha devoted more space to the issue (257 stories compared to 74 in 0 Globo). Attention to the issue seemed to be event driven, with frequencies of stories published by Folha experiencing high peaks in September and October. About 80 stories were published in Folha in October, following a governmental decision to broaden the special permission allowing the growth and commercialization of smuggled GM soybean (See Figure 2).

As expected, the majority of the stories referred to the political arena, which confirmed that the issue was in the "political arena" of Nisbet's mediated issue development cycle, the Presidency and the National Congress being mentioned in 93 percent of $O$ Globo stories and 67 percent of Folha. CTNBio, the national technical commission for biosafety, was mentioned in respectively 29 percent and 20 percent on the stories. Scientific arenas were present in about 10 percent of the stories of both newspapers. Monsanto, the international company producing and marketing the GM soybean seeds smuggled from Argentina, was mentioned in about 25 percent of the stories. About half of the stories published by $O$ Globo and 60 percent of the stories published by Folha were about GM soybean; the second most mentioned crop was corn (less than 8 percent in both newspapers).

Coverage of the GM crop issue was significantly different in the two newspapers under study, as 


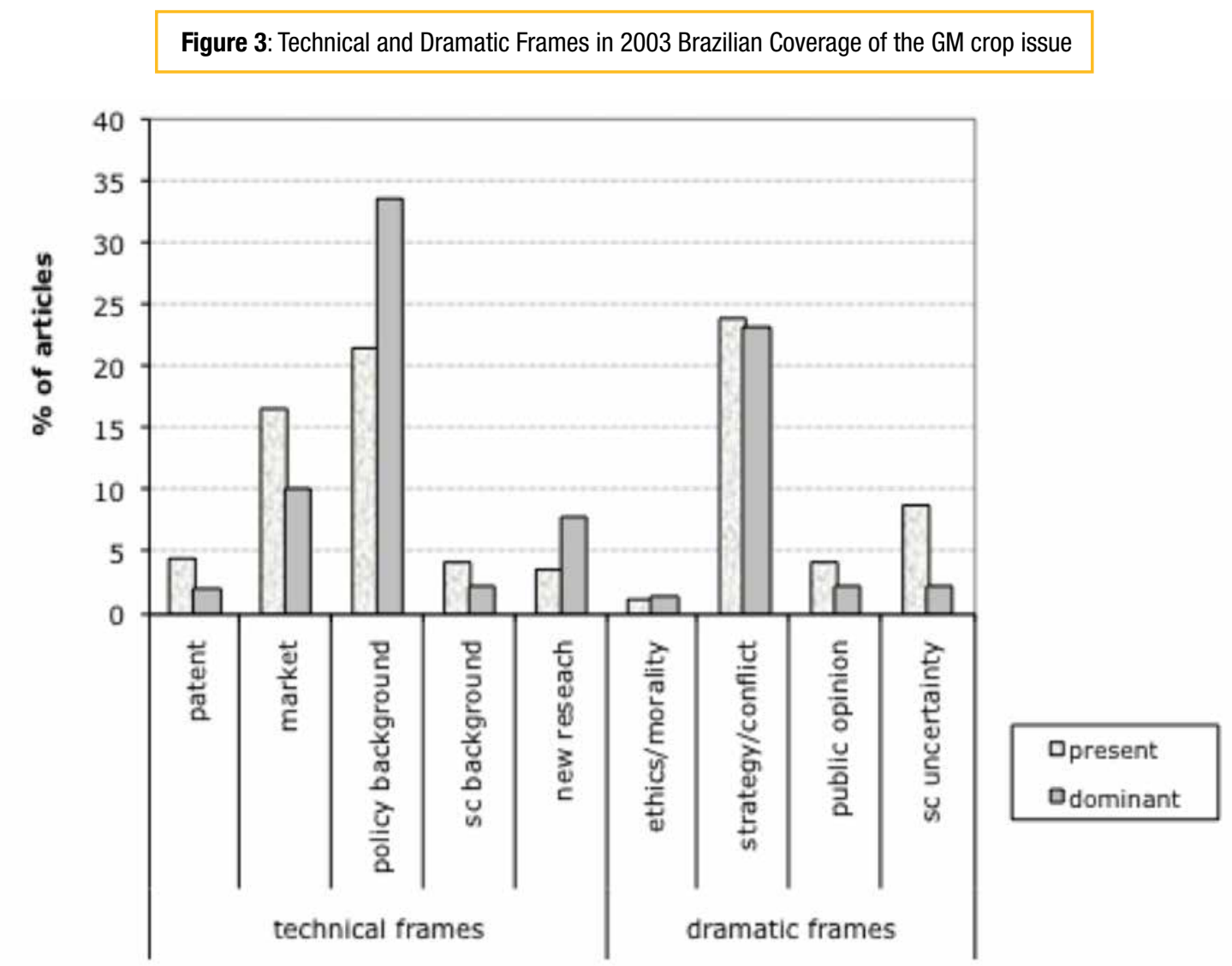

far as placement of the stories was concerned.

One fifth of the stories published by $O$ Globo

were located in the science section (which is a subsection of the international section), 35 percent in the national news section and 14 percent in sections devoted to economic issues. The figures are very different for Folh $a$, with 63 percent of the stories published in section devoted to economic issues, about 10 percent in the science section and about 5 percent in the supplement devoted to agriculture (see Figure 3).

The use of sources was similar in both newspapers. A significant proportion of the sources used by the journalists in their stories were government representatives (63 percent in Folh $a$ and 59 percent in $O$ Globo). The scientific community was mentioned less often in both papers: the scientific academies, which include the Brazilian Academy of Science and the Brazilian Society for the Advancement of Science, were used as sources in about 20 percent of the $O$ Globo stories and in about 8 percent of the Folha stories, and experts in 25 percent of $O$ Globo stories in about 15 percent of Folha stories published by Folha. Representatives from environmental organizations were mentioned in 13 percent of $O$ Globo and less than 5 percent of Folha stories. The slightly different use of sources might be explained by the different placement of the stories in both newspaper, as well as a different angle given to the stories. 
The analysis of the technical and dramatic frames in the Brazilian stories revealed that the pattern was very different from the one observed in the American coverage. Although dramatic frames were shown to be predominant in American stories covering GM food and crops when this issue was discussed in the political arena (NISBET; HUGE, 2006), this was not the case for the Folh $a$ and $O$ Globo stories. As shown in Figure 3, the Brazilian stories tended to focus on policy background related information (dominant in close to 35 percent of the stories, and present in an additional 22 percent) although dramatic elements were also stressed through the conflict frame (dominant in close to 25 percent of the stories and present in an additional 25 percent) (see Figure 3 ). The departure from the dramatic frames was extremely clear for $O$ Globo and more mixed for Folha (see Figure 4). This seems to suggest that the arena in which the issue was located was not a major determinant of the coverage.

The differential treatment of information related to GM crops in two elite Brazilian newspapers was further investigated through in-depth interviews with journalists and editors.

Media Frame Building:

Results of the In-Depth Interviews

Consistently with American journalistic norms, three of the six interviewees mentioned that their stories always presented all sides of a

Figure 4: Frames in $\underline{0 \text { Globo }}$ and Folha de S.Paulo coverage of GM Crops in 2003.

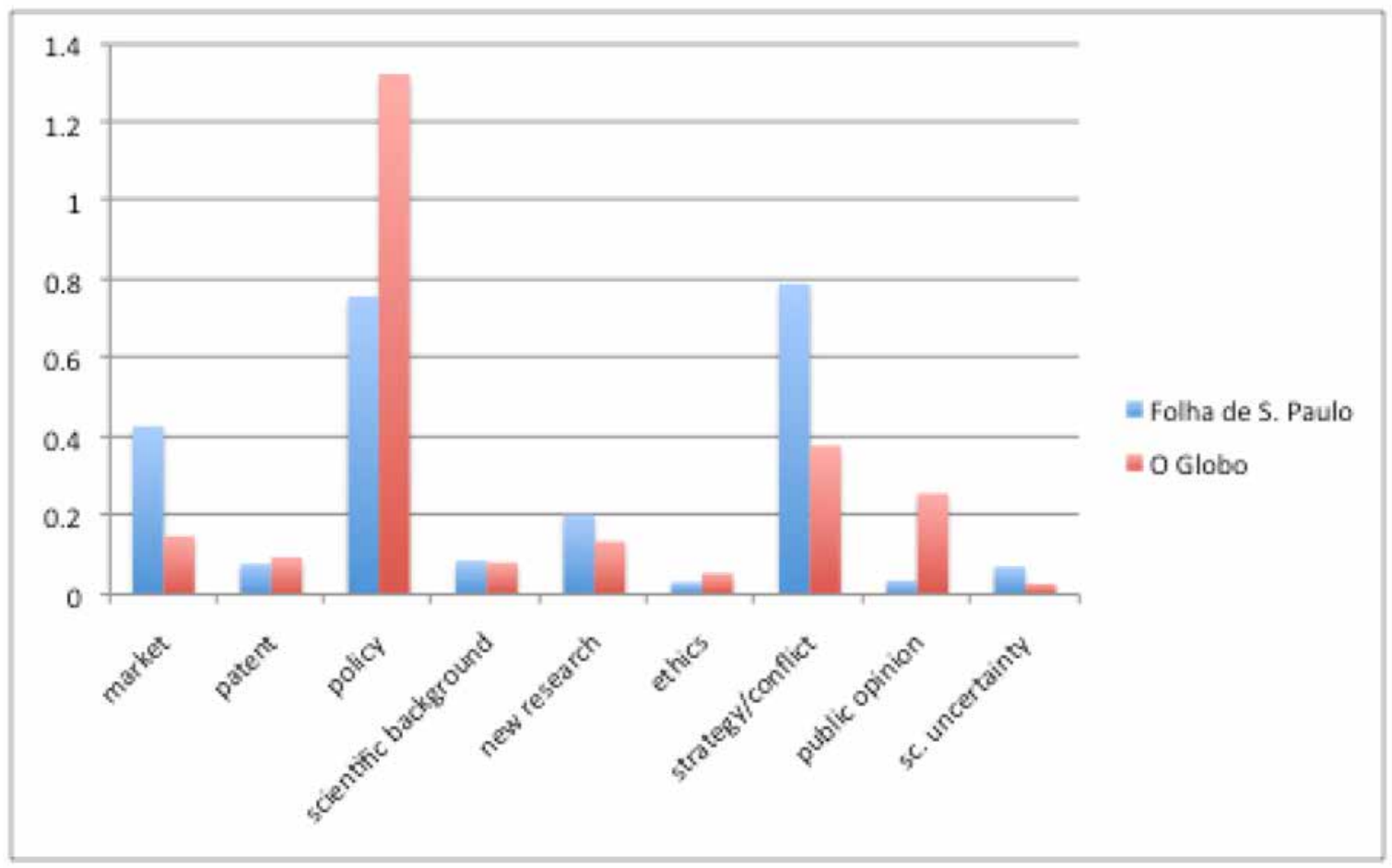


debate (balance). Five journalists used words and phrases such as "impartial," "not making judgments," and "neutral," and stressed that their reporting thrived to be as objective as possible.

There were a total of 19 different sources mentioned by the journalists. These were in line with the results of the content analysis, which highlighted government representatives as the most frequent sources of information. Journalists also mentioned industry researchers/scientists and Greenpeace as the most used sources for the issue of GM crop. Two of the journalists said they also used Monsanto, Brazilian Institute of Consumer Defense, and Council of Information on Biotechnology as sources, consistent with the content analysis results.

The interviews with the journalists revealed that the most prominent news value was relevance to the audience, with half of interviewees (all from Folha) stressing this point. One journalist says:

\section{It is a subject that encompasses the interests of common people because it involves food, right? So, there are always these fears of allergies and of damage to the environment, etc., worries that are part of people's everyday life.}

Interestingly, this aspect did not translate into the used of a public opinion frame in media coverage. Additional analysis showed that it did translate into coverage of risks and benefits related to the issue (GM related risks were mentioned in 24 percent of the stories published by $O$ Globo and in 20 percent of the stories published in Folha; meanwhile benefits were mentioned in respectively about 30 percent and 14 percent of the stories).

The controversial aspect of the issue was stressed as being a major determinant of media coverage by four out of the six journalists, suggesting that conflict was considered a major news value, and explaining the relatively important room given to the strategic/conflict frame in the coverage. This was particularly apparent for $O$ Globo journalists, one stressing that "anything that is innovative and controversial attracts newspapers ... /GM crops] were [in 2003] not at all scientific, it was a fight ..." while the other mentioned that the "advance in technology generated a debate." One of the Folha journalists explicitly mentioned the controversy as a driver of coverage but also says “...you have a public interest in this discussion about biosafety and about regulation that has been going on since 1998, it provokes and still provokes all this commotion." Another Folha journalist says: "you end up covering the debate; soy is good, it is bad, allow it, don't allow it; it is a political issue, and this is the debate." These two slightly different journalistic stances in the two newspapers might explain the somewhat different focus on policy background in stories published in Folha compared to $O$ Globo (Figure 3).

None of the journalists interviewed mentioned interest group pressure as an explanation for the 
type of coverage, or use of press releases as a tool. Two journalists mentioned that the managements of both papers were asking for reporting on the issue of GM crop, suggesting as expected some level of organizational pressure. However, the majority of the interviewees mentioned that personal preferences and choice drove the reporting, with answers generally revolving around a general enjoyment of the topic of GM crops or of science more broadly. Three of the four interviewees felt that audience values drove the coverage of GM crops with one journalist stating:

\section{Biotech is something that readers really} like; [journalists] like it because they see that the public likes it. Truth be told, there are polls that show that $O$ Globo readers like science.

However, even if "sports and science are desks that work," as mentioned by one the $O$ Globo journalist (hence the "science" location for 20 percent of the $O$ Globo stories), as we saw in our content analysis, policy was the main angle chosen in the stories. Journalists and editors did not seem to consider that the technological aspects were linked to the genetically modified crops debate, at least as it related to soybean. The placement of the stories in the Science section of $O$ Globo seemed to be driven mainly by history (this is where most GM stories ended prior to the 2003 debate), than by the specific issue under discussion (the soybean affair, mainly political).
In contrast, and in accordance with the placement of the stories in the economic section of the paper, two Folha journalists stressed the "newsworthiness" potential of giving an economic angle to the issue:

$$
\begin{aligned}
& \text { The economic angle sells ... [it is I a } \\
& \text { coverage that I think it typical of the } \\
& \text { coverage of power. You get into economy, } \\
& \text { because there are a thousand interests, there } \\
& \text { was the government, NGOs, producers' } \\
& \text { pressuring for one thing and these things } \\
& \text { were kind of mixed together. }
\end{aligned}
$$

Three of the six journalists interviewed felt that the issue was mainly an economic one, which explains the importance given to the "market" frame in the coverage.

Consistently with the nature of the coverage, the scientific background of the issue was not discussed by the journalists during the interviews.

\section{Politics started two or three years ago ... it was actually as a political theme, a party fight... it stayed on the national agenda for that very reason, it was not at all scientific, it was a fight...It was a fight between parties.}

Only one of the journalists interviewed mentioned the technicity of the issue (which could translate into a "scientific background" frame). However and as expected, journalists stressed the 
importance to explain the issue to the readers from a political or economical perspective: "You get in this that everyone is wrong, a wonderful thing, very different opinions, ... [but] people need to understand the political context."

In sum, the interviews with journalists confirmed that the frames apparent in the stories reflected the importance given to some dimensions of the issue of GM crops by the journalists themselves, as well as some organizational pressure created by the placement of the stories in specific section of the newspapers. The controversial element of the issue was a major determinant of the reporting, although the importance in explaining the context was also stressed by the journalists.

\section{Conclusion}

The goal of this study was to analyze how two elite national newspapers in Brazil covered the issue of GM crops during a period of intense political debate, the year of 2003. Our results showed that unlike their American counterparts, these newspapers did not particularly emphasize a dramatic element in their stories. This suggests that, although science and technology development are global enterprises, reporting on politicized controversial science is culturally bound.

Before elaborating on our findings in more detail, it is important to address some limitations of our study. First, Brazil has hundreds of newspapers - most of them at the local level - and we are aware that our analysis cannot be generalized to all Brazilian print media. It should be noted, however, that the two newspapers included in this study are widely read by policymakers and are likely to set the agenda of a number of media outlets in Brazil.

Second, we based our study on a conceptualization of media frames that do not give credit to the complexity of this concept. For instance, our frames mixed "topical emphasis" (i.e economy or policy) with frames more related to news values (such as conflict or ethics). It also did not capture some frames that might have been specific to the Brazilian context, and that could have been identified through some initial qualitative analysis. Losing some of nuances in framing was a calculated trade off for a potential comparison with North American data, and for theory building in communication research. Future studies could expand on our results and develop a more refined typology of frames.

Our study shows that media frame building processes are embedded in cultural contexts; Brazilian journalists shared with their North American counterparts a number of journalistic values and norms, such as the need for objectivity and balance. Emphasis was put on issues relevant to the audience and newsworthy because of conflict and controversy. Media coverage did not reflect public opinion; although the journalists claimed to use audience values as a guide for coverage, most of the tone was not alarmist. 
Organizational pressure did guide, to some extent, the nature of the coverage. However, the somewhat balanced use of technical frames and dramatic frames during a period of intense political debate, a result to be contrasted to the North American context, points to the need to continue using crosscultural approaches to refine models to be used in communication research for politicized science.

\section{References}

BRASIL. Lei n. 11.105, de 24 de março de 2005.

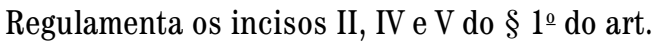
225 da Constituição Federal, estabelece normas de segurança e mecanismos de fiscalização de atividades que envolvam organismos geneticamente modificados - OGM e seus derivados, cria o Conselho Nacional de Biossegurança - CNBS, reestrutura a Comissão Técnica Nacional de Biossegurança - CTNBio, dispõe sobre a Política Nacional de Biossegurança - PNB, revoga a Lei no 8.974, de 5 de janeiro de 1995, e a Medida Provisória nº 2.191-9, de 23 de agosto de 2001 , e 0 s arts. $5^{\circ}, 6^{\circ}, 7^{\circ}, 8^{\circ}, 9^{\circ}, 10$ e 16 da Lei no 10.814 , de 15 de dezembro de 2003, e dá outras providências. Available in English at < http:// www.wipo.int/wipolex/en/text.jsp?file_id $=203933>$. Access at: 29 Sept. 2012.

BROSSARD, Dominique; SHANAHAN, James; McCOMAS, Katherine. Are issue-cycles culturally constructed? A comparison of French and American coverage of global climate change. Mass Communication and Society, n. 7, p. 359-377, 2004. DOLABELLA, Rodrigo; ARAÚJO, José; FARIA, Carmen. A lei de biossegurança e seu processo de construções no Congresso Nacional. Cadernos ASLEGIS, n. 25, p. 63-75, 2005.

DOWNS, Anthony. Up and Down with ecology: The Issue Attention Cycle. The Public Interest v. 28, p. 38-51, 1972.
GAMSON, William; MODIGLIANI, Andre. Media discourse and public opinion on nuclear power: A constructionist approach. American Journal of Sociology, v. 95, n. 1, p. 1-7, 1989.

GANS, Herbert. Deciding what's news. New York: Pantheon, 1979.

GANT, Camilla; DIMMICK, John. Making local news: A holistic analysis of sources, selection criteria, and topics. Journal of Mass Communication Quarterly, v. 77, p. $628-38,2000$.

IBOPE - Brazilian Institute on Public 0pinion and Statistics. Pesquisa de Opinião Pública sobre Transgênicos (Survey on Public Opinion on Transgenics). 2003. Available at:

$<$ www.greenpeace.org.br/transgenicos/pdf/ pesquisaIB0PE_2003.pdf>. Access at: 9 Sept. 2012. ISAAA - International Service for the Acquisition of Agri-biotech Application. Brazil grew $19 \% 160$ of the global biotech crop hectarage of million ectares in 2011. Biotech Facts \& Trends. 2012. Available at: < http://www.isaaa.org/resources/ publications/

biotech_country_facts_and_trends/download/ Facts\%20and\%20Trends\%20-\%20Brazil.pdf>. Access at: 29 Sept. 2012.

MAZUR, Allan; LEE, Jinling. Sounding the global alarm: Environmental issues in the U.S. national news. Social Studies of Science, v. 23, p. 681-720, 1993.

McCOMAS, Katherine; SHANAHAN, James. Telling stories about climate change: Measuring the impact of narratives on issue cycles. Communication Research, v. 26, n. 1 , p. 30-57, 1999.

NISBET, Matthew; BROSSARD, Dominique; KROEPSCH, Adrianne. Framing Science: The Stem Cell Controversy in an Age of Press/Politics. Harvard International Journal of Press/Politics, v. 8, n. 2, p. 36-70, 2003. 
NISBET, Matthew; HUGE, Mike. Attention cycles and frames in the plant

biotechnology debate: Managing power and

participation through the press/policy connection.

Harvard International Journal of Press/Politics, v. 11, n. 2, p. 3-40, 2006.

SCHEUFELE, Dietram. Framing as a theory of media effects. Journal of Communication, v. 49, n. 1, p. 103, 1999 .

SHOEMAKER, Pamela; REESE, Stephen. Mediating the message. 2nd ed. White Plains, NY: Longman, 1996.

TEWKSBURY, David; SCHEUFELE, Dietran. News framing theory and research. In: BRYANT, Jennings; OLIVER, Mary Beth (Org.). Media effects: Advances in theory and research. New York: Routledge, 2008.

TRUMB0, Craig. Constructing climate change: Claims and frames in U.S. news coverage of an environmental issue. Public Understanding of Science, v. 5, p. 26983, 1996.

TUCHMAN, Gaye. Making news: A study in the construction of reality. New York: Free Press, 1978.

UNGAR, Sheldon. The rise and (relative) decline of global climate change as a social problem. The Sociological Quarterly, n. 33, p. 483-501, 1992. 
Appendix 1 - Frames

\begin{tabular}{|c|c|}
\hline Technical frames & Description \\
\hline New research & $\begin{array}{l}\text { New research released, discovery announced, new medical or scientific } \\
\text { application announced, clinical trial results announced. }\end{array}$ \\
\hline Scientific background & General scientific, technical, or medical background of the issue \\
\hline $\begin{array}{l}\text { Policy and/or regulatory } \\
\text { background }\end{array}$ & $\begin{array}{l}\text { Regulatory rules for agricultural biotechnology/ framework for regulation/ } \\
\text { jurisdiction or oversight over research. }\end{array}$ \\
\hline Market/economic prospects & $\begin{array}{l}\text { International trade, imports/exports, agricultural commodity prices, } \\
\text { company market share, stock prices, company mergers and takeovers, } \\
\text { overall growth or health of industry, financial health of farmers, reaction } \\
\text { of investors, development/introduction of products for market, implications } \\
\text { for domestic economy, global competitiveness, and free/fair trade }\end{array}$ \\
\hline Patenting, property rights & $\begin{array}{l}\text { Focuses on ownership and control of new research, control and } \\
\text { ownership of seeds or field and market products, patenting/patent approval } \\
\text { of new crop strains, or discussion of national, international, or cross-national } \\
\text { property rights, such as international agreements, such as Trade-Related } \\
\text { Aspects of Intellectual Property Rights (TRIPs) of WTO }\end{array}$ \\
\hline
\end{tabular}

\begin{tabular}{|c|c|}
\hline Dramatic frames & \multicolumn{1}{c|}{ Description } \\
\hline Ethics and morality & \multicolumn{1}{|c|}{ The ethics or morality of GM agricultural practice } \\
\hline Conflict and strategy & $\begin{array}{r}\text { The political strategy, political actions, or political deliberations } \\
\text { of political figures, Presidential administrations, members of Congress, } \\
\text { other elected government, government agencies. }\end{array}$ \\
\hline Scientific uncertainty & $\begin{array}{r}\text { Includes emphasis on contesting the results of field trials or human health trials, } \\
\text { uncertainty about the ability to reliably sort in harvesting and processing non-GM0 and } \\
\text { GM0 crops, or ensure that food products contain no GM0 products. Or criticism of scientific } \\
\text { claims of opponents, dismissing as not legitimate or 'sound science.' }\end{array}$ \\
\hline $\begin{array}{r}\text { Includes focus on the 'precautionary principle,' definition of environmental and } \\
\text { Public opinion }\end{array}$ & $\begin{array}{r}\text { Focus on poll results, reporting of public opinion statistics, } \\
\text { reference to public/consumer 'support,' 'awareness,' 'concern,' } \\
\text { 'education,' 'demands,' 'backlash,' etc. or general reference to } \\
\text { 'public opinion,' 'public sentiment,' or the 'battle over' public opinion. }\end{array}$ \\
\hline
\end{tabular}




\section{Construção de frame na mídia e cultura: 0 s cultivos transgênicos em dois jornais brasileiros no "Ano da Controvérsia"}

\section{Resumo}

Brasil é o segundo produtor mundial de cultivos transgênicos. No entanto, houve intensa controvérsia em torno da introdução de tais plantações no país. Este estudo analisa a cobertura dos cultivos transgênicos em dois jornais de elite brasileiros, Folha de S. Paulo e O Globo, em 2003, 0 "Ano da Controvérsia", período de intenso debate político sobre a questão no país. Utilizamos como referenciais teóricos ciclo de atenção e construção de frame mediático, associando análise quantitativa de conteúdo e entrevistas em profundidade com jornalistas visando identificar os principais fatores que influenciaram a cobertura jornalística. Nosso estudo revelou que os dois jornais cobriram o tema de forma diferente do que ocorreu nos Estados Unidos. Os jornais norte-americanos tenderam a enfatizar elementos dramáticos quando a questão dos transgênicos era discutida na arena política; no Brasil, elementos técnicos foram um foco principal nas matérias.

\section{Palavras-chave}

Cultivos transgênicos. Análise de conteúdo. Ciclo de atenção. Frame mediático. Jornais diários.

\section{Construcción de frame en los medios masivos y cultura: Los cultivos transgénicos en dos diarios brasileños en el "Año de la Controversia"}

\section{Resumen}

Brasil es el segundo productor mundial de cultivos transgénicos. Sin embargo, hubo intensa controversia alrededor de la introducción de dichos cultivos en el país. Este estudio analiza la cobertura de los cultivos transgénicos en dos diarios de elite brasileños, Folha de S. Paulo y O Globo, en 2003, el "Año de la Controversia", período de intenso debate político sobre el tema en el país. Utilizamos como referenciales teóricos el ciclo de atención y construcción de frame mediático, asociando análisis cuantitativa de contenido y entrevistas en profundidad con periodistas visando identificar los principales factores que podrían influenciar la cobertura periodística. Nuestro estudio reveló que los dos diarios reportaran el tema de forma distinta de lo ocurrió en EE.UU. Los diarios norteamericanos tuvieran la tendencia a enfatizar elementos dramáticos cuando el tema de los transgénicos era discutido en la arena política; en Brasil, elementos técnicos fueran un foco principal en las notas.

\section{Palabras clave}

Cultivos transgénicos. Análisis contenido. Ciclo de atención. Construcción de frame mediático. Diarios. 


\section{Expediente}

A revista E-Compós é a publicação científica em formato eletrônico da Associação Nacional dos Programas de Pós-Graduação em Comunicação (Compós). Lançada em 2004, tem como principal finalidade difundir a produção acadêmica de pesquisadores da área de Comunicação, inseridos em instituições do Brasil e do exterior.
E-COMPÓS I www.e-compos.org.br I E-ISSN 1808-2599

Revista da Associação Nacional dos Programas

de Pós-Graduação em Comunicação.

E-compós, Brasília, v.16, n.1, jan./abr. 2013

A identificação das edições, a partir de 2008 ,

passa a ser volume anual com três números.

\section{CONSELHO EDITORIAL}

Afonso Albuquerque, Universidade Federal Fluminense, Brasil Alberto Carlos Augusto Klein, Universidade Estadual de Londrina, Brasil Álvaro Larangeira, Universidade Tuiuti do Paraná, Brasil André Luiz Martins Lemos, Universidade Federal da Bahia, Brasil Ângela Freire Prysthon, Universidade Federal de Pernambuco, Brasil Angela Cristina Salgueiro Marques, Faculdade Cásper Líbero (São Paulo), Brasil Antonio Roberto Chiachiri Filho, Faculdade Cásper Líbero, Brasil Arthur Autran Franco de Sá Neto, Universidade Federal de São Carlos, Brasi Benjamim Picado, Universidade Federal Fluminense, Brasil César Geraldo Guimarães, Universidade Federal de Minas Gerais, Brasil Cristiane Freitas Gutfreind, Pontifícia Universidade Católica do Rio Grande do Sul, Brasil

Denilson Lopes, Universidade Federal do Rio de Janeiro, Brasil Eduardo Peñuela Cañizal, Universidade Paulista, Brasil

Eduardo Vicente, Universidade de São Paulo, Brasil Eneus Trindade, Universidade de São Paulo, Brasil Erick Felinto de Oliveira, Universidade do Estado do Rio de Janeiro, Brasil Florence Dravet, Universidade Católica de Brasília, Brasil Gelson Santana, Universidade Anhembi/Morumbi, Brasil Gislene da Silva, Universidade Federal de Santa Catarina, Brasil Guillermo Orozco Gómez, Universidad de Guadalajara Gustavo Daudt Fischer, Universidade do Vale do Rio dos Sinos, Brasil Hector Ospina, Universidad de Manizales, Colômbia Herom Vargas, Universidade Municipal de São Caetano do Sul, Brasil Inês Vitorino, Universidade Federal do Ceará, Brasil Jay David Bolter, Georgia Institute of Technology Jeder Silveira Janotti Junior, Universidade Federal de Pernambuco, Brasil John DH Downing, University of Texas at Austin, Estados Unidos José Afonso da Silva Junior, Universidade Federal de Pernambuco, Brasil José Carlos Rodrigues, Pontifícia Universidade Católica do Rio de Janeiro, Brasil José Luiz Aidar Prado, Pontifícia Universidade Católica de São Paulo, Brasil Kelly Cristina de Souza Prudêncio, Universidade Federal do Paraná, Brasil.
Laan Mendes Barros, Universidade Metodista de São Paulo, Brasil Lance Strate, Fordham University, USA, Estados Unidos Lorraine Leu, University of Bristol, Grã-Bretanha Lucia Leão, Pontifícia Universidade Católica de São Paulo, Brasil Malena Segura Contrera, Universidade Paulista, Brasil

Márcio de Vasconcellos Serelle, Pontifícia Universidade Católica de Minas Gerais, Brasil

Maria Aparecida Baccega, Universidade de São Paulo e Escola Superior de Propaganda e Marketing, Brasil

Maria Ataide Malcher, Universidade Federal do Pará, Brasil

Maria das Graças Pinto Coelho, Universidade Federal do Rio Grande do Norte, Brasil Maria Immacolata Vassallo de Lopes, Universidade de São Paulo, Brasil Maria Luiza Martins de Mendonça, Universidade Federal de Goiás, Brasil Mauro de Souza Ventura, Universidade Estadual Paulista, Brasil Mauro Pereira Porto, Tulane University, Estados Unidos Mirna Feitoza Pereira, Universidade Federal do Amazonas, Brasil Nilda Aparecida Jacks, Universidade Federal do Rio Grande do Sul, Brasil Osvando J. de Morais, Universidade de Sorocaba, Brasil Potiguara Mendes Silveira Jr, Universidade Federal de Juiz de Fora, Brasil Renato Cordeiro Gomes, Pontifícia Universidade Católica do Rio de Janeiro, Brasil Robert K Logan, University of Toronto, Canadá

Ronaldo George Helal, Universidade do Estado do Rio de Janeiro, Brasil Rose Melo Rocha, Escola Superior de Propaganda e Marketing, Brasil Rossana Reguillo, Instituto de Estudos Superiores do Ocidente, Mexico Rousiley Celi Moreira Maia, Universidade Federal de Minas Gerais, Brasil Sebastião Guilherme Albano da Costa, Universidade Federal do Rio Grande do Norte, Brasil

Simone Maria Andrade Pereira de Sá, Universidade Federal Fluminense, Brasil Tiago Quiroga Fausto Neto, Universidade de Brasília, Brasil Suzete Venturelli, Universidade de Brasília, Brasil Valerio Fuenzalida Fernández, Puc-Chile, Chile

Veneza Mayora Ronsini, Universidade Federal de Santa Maria, Brasil Vera Regina Veiga França, Universidade Federal de Minas Gerais, Brasil

\section{COMISSÃO EDITORIAL}

Adriana Braga I Pontifícia Universidade Católica do Rio de Janeiro, Brasil

Felipe Costa Trotta I Universidade Federal Fluminense, Brasil

CONSULTORES AD HOC

Bruno Campanella, Universidade Federal Fluminense, Brasil

Christa Berger, Universidade do Vale do Rio dos Sinos, Brasil

Edison Gastaldo, Universidade Federal Rural do Rio de Janeiro, Brasil

José Luiz Braga, Universidade do Vale do Rio dos Sinos, Brasil

\section{EDIÇÃO DE TEXTO E RESUMOS I Susane Barros}

SECRETÁRIA EXECUTIVA I Juliana Depiné

EDITORACã̃ ELETRÔNICA I Roka Estúdio
COMPóS I www.compos.org.br

Associação Nacional dos Programas de Pós-Graduação em Comunicação

Presidente

Julio Pinto

Pontifícia Universidade Católica de Minas Gerais, Brasil juliopinto@pucminas.br

Vice-presidente

Itania Maria Mota Gomes

Universidade Federal da Bahia, Brasil

itania@ufba.br

Secretária-Geral

Inês Vitorino

Universidade Federal do Ceará, Brasil

inesvic@gmail.com 